City University of New York (CUNY)

CUNY Academic Works

Publications and Research

Baruch College

Fall 2011

\title{
Censuring the Praise of Alienation: Interstices of Ante-Alienation in Things Fall Apart, No Longer At Ease, and Arrow of God
}

Kevin Frank

CUNY Bernard M Baruch College

How does access to this work benefit you? Let us know!

Follow this and additional works at: https://academicworks.cuny.edu/bb_pubs

Part of the African Languages and Societies Commons, Literature in English, Anglophone outside British Isles and North America Commons, and the Race, Ethnicity and Post-Colonial Studies Commons

\section{Recommended Citation}

Frank, Kevin, "Censuring the Praise of Alienation: Interstices of Ante-Alienation in Things Fall Apart, No Longer At Ease, and Arrow of God" (2011). CUNY Academic Works.

https://academicworks.cuny.edu/bb_pubs/187 


\title{
CENSURING THE PRAISE OF ALIENATION Interstices of Ante-Alienation in Things Fall Apart, No Longer at Ease, and Arrow of God
}

by Kevin Frank

A country's novels reveal its social condition.

-F. J. Pedler, West Africa

\begin{abstract}
Alienation has long been a preoccupation of modern African novels and of critical responses to them, which is as one might expect given the writers of these novels are for the most part those who in one way or another were alienated from their native tongues and cultures through their schooling in the colonizer's language and culture, at home and/or abroad. But many critical perspectives on these works are circumscribed by the tendency to view alienation as resulting primarily from external forces operating upon natives, and to overlook former detachment. Additionally, a key component of alienation is often overlooked, as if taken for granted: that there needs to have been a former attachment. In this respect colonial alienation is sometimes a meta-alienation, following natives' prior alienation from their culture. In his landmark essay, "In Praise of Alienation," Abiola Irele's broad assessment is correct: "All of our modern expression in literature and ideology has developed from a primary concern with the pathology of alienation as inscribed in our experience as a colonized people" (202). His observation that "the writer who seems, in fact, to have engaged our responses most forcefully upon the problem of alienation is Chinua Achebe" (Irele, "In Praise" 203-4) is also accurate. Indeed, there is an awful lot to agree with in Irele's groundbreaking work, and even at this late stage he continues to deserve plaudits for his insightful mind and for his courage in taking the road less traveled on this and other subjects related to African and postcolonial experiences, including his decrying African industrial, moral, and intellectual indolence ("In Praise" 212). However, our reverence for the great scholar should not blind us to an important shortcoming in his polemic, which has surprisingly gone unchallenged. That is, he over generalizes when he contends, "What runs through all this literature is the feeling that it is within our traditional culture that we are happiest, most at ease with ourselves, that there is the truest coincidence between us and the world: in other words, that our identity is located" ("In Praise" 204, emphasis added). Moreover, he adds, "The whole movement of mind in Black cultural nationalism, from Blyden to Senghor, leads to a mystique of traditional forms of life" ("In Praise" 205).

In this essay, among other things, I interrogate Irele's claim about happiness and ease within traditional culture. The "feeling" he refers to is predicated on a static view of Négri-
\end{abstract}


tude, on what, in The African Experience in Literature and Ideology, he calls "a romantic myth of Africa" (Irele 68), or what Gregson Davis identifies in Aimé Césaire as nostalgia for an ideal state located in traditional African culture (181). Irele's remark of the romanticism of traditional African culture in the style, makeup, and symbolism of Camara Laye's work is easily affirmed, especially in The African Child ("In Praise" 204). But, his painting of Chinua Achebe with the same brush, albeit with a more tentative stroke-"It [the mysticism] is not altogether absent from Achebe's novels" ("In Praise" 204)—must be disputed. The overwhelmingly binary focus on tradition versus alienation, or traditional culture as the repository against and after colonial alienation, has its limitations. The following analysis transcends these limitations by re-examining alienation primarily in Things Fall Apart and No Longer at Ease, but also in the very work that Irele considers Achebe's "masterpiece" ("In Praise" 204) on the topic: Arrow of God. This investigation focuses somewhat on externalization following colonial incursions or international travel by the colonized, which engenders ambivalence and psychological trauma stemming from negative feelings about the native culture, or the perceived lack thereof, relative to the colonizer's culture. But the main thrust of my examination is the subtler and, I argue, equally dangerous agent of externality: ante-alienation, or social alienation within traditional African culture, which precedes racially based, colonial alienation. The ante-alienation in these texts challenges Négritude's paradisiacal view of Africa and raises questions about Africans always being happiest or most at ease with themselves within their traditional culture.

Things Fall Apart, No Longer at Ease, and Arrow of God illustrate that alienation also results from intra-national migrations, both travel within the home state and changes in the native's position and disposition relative to the larger, national or cultural body and mind. On the one hand, these movements sometimes result from colonial schemes. On the other hand, sometimes they predate colonialism, and they cause interstices in cultural continuity. Pre-existing breaks enable the success of colonial interventions in that, as a result, natives are turned or help to turn themselves into objects, a process that is, after all, at the root of alienation. My exposition of these works leads naturally to questioning a few of Irele's other positions in "In Praise of Alienation," especially regarding modernity. For instance, disputing the value of traditional culture and differentiation resulting from Afro-centric ideologies such as Négritude, he argues, "Traditional culture produces children better adapted for life. But it depends what life: in the village or in the city, in the traditional culture or in the modern culture" ("In Praise" 214). Here I am neither interested in making a case, as Irele does, for alienation, nor in purporting the false hope of a return to tradition as part and parcel of a cultural nationalism that arguably never was. I am, instead, concerned with whether or not these novels image pure coherence in traditional culture, and if these novels indicate that alienation advances the African's ability to cope with modernity's demands, as Irele implies. In other words, is alienation worthy of some of the praise assigned to it? 
Things Fall Apart rightfully continues to be a standard-bearer in postcolonial literature. It is, after all, one of the earliest African novels written from the perspective of the colonized to sound the alarm concerning the three phases and the treacherous practices of colonialism. The initial phase, the exploratory, is suggested in the novel when, during Okonkwo's second year of exile, his friend Obierika visits and tells him of the appearance of a white man in their clan: "The elders consulted their Oracle and it told them that the strange man would break their clan and spread destruction among them ... And so they killed the white man and tied his iron horse to their sacred tree" (Achebe, Things 138). Obierika adds: "I forgot to tell you another thing which the Oracle said. It said that other white men were on their way. They were locusts, it said, and that first man was their harbinger sent to explore the terrain" (138-39). The second phase of colonialism, conversion, also begins during Okonkwo's exile: "When nearly two years later Obierika paid another visit to his friend in exile the circumstances were less happy. The missionaries had come to Umuofia. They had built their church there, won a handful of converts and were already sending evangelists to the surrounding towns and villages" (143). The third phase, the administrative, is hinted at when the narrator comments somewhat forebodingly, "But stories were already gaining ground that the white man had not only brought a religion but also a government. It was said that they had built a place of judgment in Umuofia to protect the followers of their religion" (155). Here we see an example of a rationale developed for the judicial system that's implanted: the need for protection.

The true nature of that "government" and "judgment" is exposed in the coalescence of religious and administrative interests in suppressing the natives after they are enraged when one of the converts to Christianity, Enoch, unmasks an egwugwu in public (Things 186). Receiving no satisfaction for this violation from missionary Brown's uncompromising successor, Mr. Smith, the Umuofians burn the church to the ground (191). After "a long discussion" (192) between Mr. Smith and the District Commissioner, the latter traps the leaders of Umuofia in his courthouse and his men exact revenge by brute force (195). This brutality makes the commissioner's claim, "We have brought a peaceful administration to you and your people so that you may be happy," sound very hollow (194). The lie of his "civilizing mission," referred to as "peace and good government" (198), is further exposed in the presumptuousness and irony of his book title, "The Pacification of the Primitive Tribes of the Lower Niger" (209), wherein "pacification" is merely a euphemism for violent suppression. The predetermined title, before the "student" has done any research, gives away his lack of objectivity, the prejudice that guides his perspective and actions.

Passages surrounding Enoch's unmasking of the egwugwu may be misread as indicating Achebe's mysticism of traditional culture. For example, as the narrator observes, "One of the greatest crimes a man could commit was to unmask an egwugwu in public, or to say or do anything which might reduce its immortal prestige in the eyes of the uninitiated" (Things 186). Furthermore, of the consternation and bemoaning that follows the unmasking, we are told, "It seemed as if the very soul of the tribe wept for a great evil that was coming - its own death" (187). Viewed holistically, however, these passages remind us of the brilliant ways in which Achebe's formal and symbolic elements are seamlessly merged. The unmasking of the egwugwu, far from evidencing mystique, is a good occa- 


\section{A L L A L O O}

sion marking Achebe's unmasking of tradition. That is, the egwugwu have already been demystified or symbolically unmasked in the text. This occurs, for instance, when the egwugwu gather to administer justice in the case of Uzowulu versus Mgbafo. The narrator describes: "Okonkwo's wives, and perhaps other women as well, might have noticed that the second egwugwu had the springy walk of Okonkwo. And they might also have noticed that Okonkwo was not among the titled men and elders who sat behind the row of egwugwu" (89-90). In other words, the women recognize and willingly preserve the performative aspects of the exercise. Achebe deconstructs any potential romanticism of even this most sacred element of traditional culture by bringing this awareness to the readers' attention, and by signifying the participants' perception.

In literary criticism social alienation is often treated as a problem of the colonized intelligentsia. Though Okonkwo is certainly among his society's elite, his estrangement does not really result from intellectual pursuit. Okonkwo's isolation is the punishment according to his own clan's laws of justice, before the imposition of foreign rule. It is therefore intra-cultural: "The only course open to Okonkwo was to flee from the clan. It was a crime against the earth goddess to kill a clansman, and a man who committed it must flee from the land. The crime was of two kinds, male and female. Okonkwo had committed the female, because it had been inadvertent. He could return to the clan after seven years" (Things 124). The binary designation of crime as "male and female" and the hierarchizing signature coincidental to that designation mark gender inequalities within Umuofia, evidence of what Simon Gikandi identifies as "elements of alienation and disjunction" (34), which the Umuofian order cannot obscure. Women are already separated within the culture, signified, for instance, by their place at communal ceremonies, which they observe "from the fringe like outsiders" (Things 87). Also, Okonkwo's greatest fear, womanliness, "the fear of himself, less he should be found to resemble his father" (Things 13), indicates both his rejection of the female as a significant force within himself and the community, and of his struggles with feeling an abject figure within his society because of his father, a sentiment he tries extremely hard to overcompensate for. These are signs of incohesion in the culture.

The gender-based cleavage within traditional Umuofian culture prefigures the gendered, colonial imagination of native landscapes to be conquered and natives to be subdued: "He [Okonkwo] trembled with the desire to conquer and subdue. It was like the desire for woman" (Things 42). Furthermore, the gender problems are connected to Okonkwo's impatience and violence in demonstrating his masculinity while suppressing any signs of femininity. His attitude is consistent with the male dominance of his culture and contributes to his exile. The point is underscored ironically in his exile among the female line of his ancestry. As Okonkwo's uncle, Uchendu, declares, “We are only his mother's kinsmen. He does not belong here. He is an exile, condemned for seven years to live in a strange land" (133). Yet, Okonkwo's exile among his mother's kin is an occasion for him to be reminded of his culture's greater, harmonic gender outlook, an opportunity for him to reject his dislocating hyper-masculine ideals and tendencies: "A man belongs to his fatherland when things are good and life is sweet. But when there is sorrow and bitterness he finds refuge in his motherland. Your mother is there to protect you" (134). Irele's notion that "the phenomenon of alienation in its positive aspect is the generating principle of culture, the condition of human development" has some bearing here in that 
Okonkwo's alienation is an opportunity for his development ("In Praise" 222). As Will Harris remarks fittingly in his essay "Okonkwo in Exile," Okonkwo's exile is consistent with "the heroic quest-often a form of exile-the voyage during which the voyager is isolated from familiar circumstances and 'permitted' to learn" (94). Yet Okonkwo shows no interest in learning.

Uchendu's remark above about not belonging and condemnation, or what I would like to call "condemned nation"- - being in a strange land/becoming a stranger to one's own land-is also useful for examining another important way in which alienation is figured in Things Fall Apart. It is in some respects a function of the colonial process exacerbating pre-existing disconnectedness within Umuofia; the conversion of Okonkwo's son, Nwoye, is a good case in point. Nwoye's failure to exhibit the manly characteristics consistent with his father's binary, gendered worldview makes him an outcast in his own home and community, as he is forced to deny a part of himself: "Nwoye knew that it was right to be masculine and to be violent, but somehow he still preferred the stories that his mother used to tell" (53). To be representative of the entire body of the culture, that "self" must include both the masculine and the feminine. Therefore, when he succumbs to the pressure to reject "female" stories, it amounts to a form of both self-denial and the denial of a part of the larger culture, the culture of women. Like his father, he becomes dislocated from the whole. He is rebuked and beaten by his father for his preference for female stories, and these acts of condemnation mark a stage of his alienation: "That was the kind of story that Nwoye loved. But he now knew that they were for foolish women and children, and he knew that his father wanted him to be a man. And so he feigned that he no longer cared for women's stories. And when he did this he saw that his father was pleased, and no longer rebuked him or beat him" (54). These sanctions sever him from his home and community, an additional sign of an intra-cultural gap.

Another passage of Nwoye's ante-alienation occurs after his foster brother, Ikemefuna, is killed: "Something seemed to give way inside of him, like the snapping of a tightened bow" (Things 61). This snapping indicates an emotional and psychological disturbance that was already triggered by his difficulty accepting the clan's treatment of twins, a practice that predates colonialism:

Nwoye had heard that twins were put in earthenware pots and thrown away in the forest, but he had never yet come across them. A vague chill had descended on him and his head had seemed to swell ... Then something had given way inside him. It descended on him again, this feeling, when his father walked in, that night after killing Ikemefuna. (Things 61-62)

His emotional disconnection is one way in which he is othered from his culture: he becomes extrinsic to the tribe's myth of itself as holistic or unitary. Twins, one a mirror image of the other, are anathema to the tribe, a sign of the tribe's inability or unwillingness to confront dividedness or otherness. In this respect, the tribe's disavowal of twins is somewhat similar to the discriminatory discursive colonial practice illustrated by Homi Bhabha in The Location OfCulture: "Produced through the strategy of disavowal, the reference of discrimination is always to a process of splitting as a condition of subjection: a discrimination between the 


\section{A L L A L O O}

mother culture and its bastards, the self and its doubles, where the trace of what is disavowed is not repressed but repeated as something different-a mutation, a hybrid" (111). The twins are the literal doubles, the "bastards" of the tribe; whereas they are physically put out of the tribe, cast away in the Evil Forest, Nwoye joins those who are emotionally and psychologically dislocated from the clan. In other words, the literal mutations, the twins, engender a process of greater hybridity of dispositions among the tribespeople, another step in Nwoye's condemning his tribe's beliefs and practices.

In the latter respect, Nwoye's exile also bears some resemblance to the experience described by Said in Representations of the Intellectual:

Even intellectuals who are lifelong members of a society can, in a manner of speaking, be divided into insiders and outsiders: those on the one hand who belong fully to the society as it is, who flourish in it without an overwhelming sense of dissonance or dissent, those who can be called yea-sayers; and on the other hand, the nay-sayers, the individuals at odds with their society and therefore outsiders and exiles so far as privileges, power, and honors are concerned. (52-53)

Though at this point in the novel he is not yet the type of "intellectual" Said expounds upon-schooled in the colonizer's language, traditions, and values-Nwoye's critical response to his culture's gender expectations and to its treatment of twins and Ikemefuna excludes him from his society prior to his contact with the West. Ngũgĩ wa Thiong'o argues that colonial alienation takes two interlinked forms: "an active (or passive) distancing of oneself from the reality around; and an active (or passive) identification with that which is most external to one's environment" (28). When Nwoye is captured by the white man's religion, it is less because of its actual tenets and more due to its potential to help him escape his own culture's harsh, alienating realities:

It was not the mad logic of the Trinity that captivated him. He did not understand it. It was the poetry of the new religion, something felt in the marrow. The hymn about brothers who sat in darkness and in fear seemed to answer a vague and persistent question that haunted his young soul - the question of the twins crying in the bush and the question of Ikemefuna who was killed. He felt a relief within as the hymn poured into his parched soul. (Things 147)

This points to Nwoye's senses being dislocated from their normal habitat, one form of social alienation. His conversion marks the ultimate stage of his othering, his opposition to and exclusion from the beliefs and ways of his entire clan.

Interestingly, because it involves education or literacy as an objective, this last stage is also consistent with the disaffection typical of colonized intellectuals: "He went back to the church and told Mr. Kiaga that he had decided to go to Umuofia where the white missionary had set up a school to teach young Christians to read and write" (Things 152). As Frantz Fanon points out in Black Skin, White Masks, "To speak a language is to take on a world, a culture" (38); it stands to reason that Nwoye's adoption of the colonizer's culture will be that much greater as he also learns to read and write their language. Mr. Kiaga's scriptural response illustrates the greater portent of Nwoye's conversion, in terms of his 


\section{A L L A L O O}

greater alienation not only from his family but also from Umuofia's language and customs: "Mr. Kiaga's joy was very great. 'Blessed is he who forsakes his father and his mother for my sake,' he intoned" (Things 38). The word "forsakes" here implies Nwoye's movement from a sense of not belonging to a rejection of his family and culture. More evidence of that abandonment is that his (re)education and corresponding cultural dispossession involve his renaming: "He [Mr. Brown] had just sent Okonkwo's son, Nwoye, who was now called Isaac, to the new training college for teachers in Umuru" (Things 182). This cultural dispossession through colonial schooling is exactly the worry of the Diallobé chief in Cheikh Hamidou Kane's Ambiguous Adventure: "'If I told them to go to the new school,' he said at last, 'they would go en masse. They would learn all the ways of joining wood to wood which we do not know. But, learning, they would also forget. Would what they would learn be worth as much as what they would forget?'" (30). Irele appears undaunted with such concerns. After all, he insists, "We could do with a little more alienation," that is, one assumes, as an improving mechanism in the quality of African life ("In Praise" 219). The ante-alienation or intra-cultural fissures seen in Things Fall Apart show that Achebe does not fit squarely among those who idealize traditional African culture.

\section{II}

No Longer At Ease exposes the long-term ramifications of colonialism's exacerbation of forms of social alienation already existing within Umuofia and allows us to consider whether or not alienation really encourages development, improves quality of life, and is, therefore, worthy of praise. The main plot involves Isaac's (née Nwoye's) son, Okonkwo's grandson, Obi Okonkwo, the would-be hero who descends into corruption, specifically, bribery. As in its prequel, Things Fall Apart, hubris is projected as a significant contributing factor in the protagonist's downfall in No Longer At Ease. The narrator presents the heart of the matter from Obi's perspective when he finds himself in the financial crisis that leads to his succumbing to the bribery schemes endemic in Lagos:

Why had he [Obi] not swallowed his pride and accepted the four months' exemption which he had been allowed, albeit with a bad grace? Could a person in his position afford that kind of pride? Was it not a common saying among his people that a man should not, out of pride and etiquette, swallow his phlegm? (Achebe, No Longer 156)

Obi's tragedy also results from racially based, colonial alienation. A good example concerns the connotations of his language usage while abroad, in England: "When he had to speak in English with a Nigerian student from another tribe he lowered his voice. It was humiliating to have to speak to one's own countryman in a foreign language, especially in the presence of the proud owners of that language. They would naturally assume that one had no language of one's own" (Achebe, No Longer 49). Obi's fear here pertains to the myths perpetuated in the ideological war waged upon Africans: that the colonized needed the European gift of language or, at least, literacy; that the African had no history or culture 
before colonialism. In the international setting (London), a would-be intra-national social exchange is mediated by that fear.

Stephen Criswell rightly sees a similarity between Obi and Joyce Cary's Mister Johnson: "Native African protagonists, who find themselves trapped between traditional African society and Western values and culture; both novels' protagonists are isolated, alienated, disconnected individuals" (Criswell 45). In inscribing the sense of individuals caught between cultures, Achebe anticipates a common postcolonial trope: hybridization. Hybridized language suggests burgeoning hybridized selves. Ibo or Pidgin English is dropped while speaking English, but that "compositeness" is the other side of disconnectedness. One example occurs when Clara is upset at Obi: "'Leave me, ojare,' she said, snatching her hand away" (No Longer 19). Characters also switch between their native tongue and English, or Pidgin, which demarcates either social distance or cultural intimacy. For instance, when Obi is seasick while returning from England, Clara brings him medication: "'I noticed you were not looking very well,' she said in Ibo, 'so I brought you some tablets of Avomine'" (No Longer 25). Obi feels a sense of shared language, intimacy, and cultural bonding in this gesture: "But then she had spoken in Ibo, for the first time, as if to say, 'We belong together: we speak the same language'" (No Longer 25). This contrasts with his feeling like a snubbed outsider the second time he meets Clara, enough so that he takes "a firm decision not to show any interest in her" ( No Longer 25). Language plays a part in that exclusion because Clara is conversing in English with Mrs. Wright and Macmillan, a colonial administrator: "Clara introduced herself as Miss Okeke. 'I think we have met before,' said Obi. Clara looked surprised and somewhat hostile. 'At the N.C.N.C. dance in London.' 'I see,' she said, with as much interest as if she had just been told that they were on a boat in the Liverpool Docks, and resumed her conversation with Mrs. Wright" (No Longer 23).

Another example of alienating language occurs when Obi discusses his intent to marry Clara, an Osu (outcast/ untouchable), with Joseph: "'Look at me,' said Joseph, getting up and tying his coverlet as a loincloth. He now spoke in English [my emphasis]. 'You know book, but this is no matter for book. Do you know what an osu is? But how can you know?' In that short question he said in effect that Obi's mission-house upbringing and European education had made him a stranger in his country" (No Longer 71-72). Alienation here is not merely implied in Joseph's accusation regarding Obi's European influences. It is also connected to the social alienation inherent in his contemplation of marrying an Osu, thereby defying his society's caste system, which already bears the seed of separation. Cultural detachment is further signified in Joseph's shift to English to emphasize a point, as if Ibo is inadequate for the purpose. Joseph consistently defers to the colonizer's language as the carrier of important information: "Joseph always put on an impressive manner when speaking on the telephone. He never spoke Ibo or pidgin English at such moments. When he hung up he told his colleagues: 'That na my brother. Just return from overseas. B.A. (Honours) Classics.' He always preferred the fiction of Classics to the truth of English. It sounded more impressive" (No Longer 77). He appears to be among the Nigerians ineffectively negotiating the tension between what Gikandi designates as "claims of both colonial modernity and their previously degraded African mode of life" (Gikandi 82). One indication of Joseph's participation in modernity is his attempt to speak "standard" British English (or as much of it as he can) when on the phone. Irele is quite right 
in observing, "Western civilization ... provides the paradigm of modernity to which we aspire" ("Praise" 202). To Joseph, the phone is a technological symbol of that modernization correlative to the "development" of his language in the form of the mimicked accent. The message to be conveyed is that through the phone and through his "brother," he is connected to "overseas" and is, therefore, himself important. But, no matter how well executed, mimicry is not the thing itself, and Joseph's poor mimicry and empty message are merely signs of his mental underdevelopment. His alienation is certainly not serving him well and is, therefore, not worthy of praise.

There is some irony, of course, in the desired impressiveness of Classics over English: in the colonial context, British English is often seen as most impressive. Joseph's deference to British English marks a variation of Fanon's sense of the native returned from the mother country: "The fact that the newly returned Negro adopts a language different from that of the group into which he was born is evidence of a dislocation, a separation" (Fanon 25). Of course, in this case it is the friend of the returned person who is vicariously transported abroad. Yet Joseph is not alone in holding British English in high esteem and deferring to it in a way that initiates dislocation. The pattern is observable in the members' response to the secretary of the Umuofia Progressive Union's speech welcoming Obi back from abroad, suggesting something of the process through which they may be transformed into objects of colonialism: "What a sharp young man their secretary was, all said. He deserved to go to England himself. He wrote the kind of English they admired if not understood: the kind that filled the mouth, like the proverbial dry meat" (No Longer 32).

Obi's alienation, then, does not result strictly from going to England: it is also the consequence of detached states occasioned by the forced creation of the protectorate, nationstate, Nigeria, out of pre-existing kingdoms within which there were many separate tribes whose cultures were not always compatible. As Gikandi points out, "The nation in Africa is an arbitrary and often fictional colonial creation" (Gikandi 8), which is one of the reasons why the Umuofians "see themselves as foreigners in the national community" (Gikandi 85). Given its arbitrary construction, that "national community" is emerging tentatively and in a hybrid fashion. Hence, the pronouncement by the Umuofia Progressive Union's president of the Lagos branch, "'We are strangers in this land"” (No Longer 6). The foreign feeling is similarly behind the narrator's remark, "Six or seven years ago Umuofians abroad had formed their Union with the aim of collecting money to send some of their brighter young men to study in England" (No Longer 7). Consistent in these quotations is the sense of natives being abroad in what, for all extensive purposes, is their own nation. While the colonial power has supposedly created one nation out of many clans, the clansmen continue to define themselves separately, according to their nations that predated the formation of the larger nation-state. Umuofians see themselves as intra-national foreigners of sorts, as "strangers" in Lagos, and the narrator represents them as being "abroad."

Within the new "nation", the attitude towards those who have gone abroad helps to enforce social alienation. As a sign of the "progress" made by individuals on behalf of the whole, the expectation is that persons returning from abroad will become physically separated from their people. This is suggested when Obi considers lodgings after returning from England. He asks Joseph about sharing his place as he had done before leaving and Joseph retorts, "'What will the people of other towns say when they hear that a son of Umuofia returned from England and shared a room in Obalende?"' (No Longer 36). 
Joseph's question suggests that separation is expected. As a sign to all others of Obi's and, equally important, their progress, even the Umuofia Progressive Union's executive agrees with Joseph that Obi "should be put up in proper fashion at a hotel" (No Longer 35). Obi's playboy friend, Christopher, makes one of the more critical observations in the text concerning Clara, that sheds light on the politics of alienation in the work: "'You may say that I am not broad-minded, but I don't think we have reached the stage where we can ignore all our customs'" (No Longer 144). Part of the irony here is that they would indeed do well to reconsider some of their socially ante-alienating customs, such as the caste system. Yet the central connotation is that Obi's experiences abroad have left him abroadminded, to the extent that he is willing to ignore many of his customs. His experiences have made him alien to his culture. Hence, one of the other patients of the doctor who performs Clara's abortion is not far from the mark in declaring of Obi, "'Foolish man. He tink say because him get car so derefore he can do as he like. Beast of no nation!"' (No Longer 152, my italics). This sentiment is reinforced later when Obi foregoes cultural custom by not going home for his mother's funeral: "Someone else wanted to know, by the way, why that beast (meaning Obi) had not obtained permission to go home" (No Longer 159). Like Joseph's phone, Obi's car is a marker of modernization, but these symbols merely appear to improve lives when, instead, they further communal fissures.

Obi cannot return home: he is doubly alienated from it, through his studies of English both at home and abroad and through British hegemony in Nigeria, which make him and others like him feel abroad while still at home. Equally important, because of the ruptures preceding, exacerbated, and created by colonial hegemony, many of those who remain at home also become infected with an abroad-mindedness. Will Harris insightfully views the African hero's journey described by Clyde Ford as mirroring "the 'monomyth' of Joseph Campbell and Northrop Frye" (Harris 95). But the pattern of the hero's journey from home into a "literal or metaphoric (exilic) underworld" does not fit exactly for the colonized whose quest involves going to the "mother country" or attending the mother country's institutions in his or her own land. The colonized given such opportunities is trained to think he is going not to the underworld, but to the over-world, against which his home can never measure up.

III

Because Achebe's Arrow of God is set in the 1920s, after the British have made inroads among the Ibo of Nigeria, a cursory reading of novel could leave one with the impression that the alienation seen in the text results from colonialism. For example, in a very early passage, the narrator describes, "A great division had come to the six villages and his [Ezeulu's] enemies tried to put it on his head. For what reason? Because he had spoken the truth before the white man" (Achebe, Arrow 7). The land dispute between the six communal villages collectively called Umuaro and their neighboring village, Okperi, is also represented as exacerbated by colonial interference: "What they should tell us is why, if the land was indeed theirs, why they let us farm it and cut thatch from it for generation after generation, until the white man came and reminded them'"' (Arrow 22). Notwithstanding 
these passages, however, the structure of colonial exile as proceeding from intra-cultural ante-alienation is expressly evoked in the text. That structure reveals that Achebe's return to a depiction of traditional life is more intricate than an aura of mystique would allow. The complexities of the diverse Ibo society presented include its historical foibles, which antecede British impact. Firstly, the risk of alienation within Ezeulu's family is spawned by the politics of inheritance. It is why Edogo, Ezeule's eldest son, complains to Akuebue: "A man should hold his compound together, not plant dissension among his children" (Arrow 142). The narrator next summarizes Edogo's rationale for his resentment: “Edogo told him [Akuebue] that the reason why Ezeulu sent Oduche to the new religion was to leave the way clear for Nwafo to become chief priest" (Arrow 142). These details indicate that it is family politics, favoritism, and not solely colonial evangelism and administrative politics that engender familial ruptures. Secondly, but of no less import, the filial conflict within the household of Ezeulu, the paterfamilias and chief priest, is merely a microcosm of the corresponding strife and risk of division among other relatives, and among the collective tribes: "And yet Akuebue felt sorry for Edogo. He knew how a man's first son must feel to be pushed back so that the younger ones might come forward to receive favour. No doubt that was why in the first days of Umuaro, Ulu chose to give only one son to his Chief Priests, for seven generations" (Arrow 143).

It is worth noting that the same motive, filial jealously, informs perspectives of Ezeulu's estrangement from his half-brother, Okeke Onenyi:

Okeke Onenyi always said that the cause of the coolness between
him and the present Ezeulu, his half-brother, was the latter's re-
sentment at the splitting of the powers between them. 'He forgets,'
says Okeke Onenyi, 'that the knowledge of herbs and anwansi is
something inscribed in the lines of a man's palm. He thinks that our
father deliberately took it from him and gave to me. Has he heard
me complaining that the priesthood went to him?' (Arrow 166)

The narrator indicates the reason for the feud as entirely other than the one just given: "But there were others like Akuebue who knew Ezeulu better who retorted that there was something which Okeke Onenyi did to Ezeulu. It was not very clear what this thing was. All that was known was that it was not a thing which a brother should do to a brother" (Arrow 166). Moreover, he adds: "'But you forget that Okeke Onenyi has a big grudge against Ezeulu,' the others might say. 'You forget that in their childhood their father led Okeke to think that he was going to succeed to the priesthood"' (Arrow 166-167). In other words, the rift regarding the priesthood of Umuaro is generational. These examples indicate a pattern of hereditary, intra-cultural divisiveness that is not conducive to natives being happy and at ease with themselves within their traditional culture. Achebe's enunciation of this sort of internal discord intimates he is not really concerned with romanticizing traditional culture. Moreover, that antipathy delimits Irele's reading of social cohesion prior to Western contact in the images of traditional culture in modern African literature, especially as pertinent to Achebe: "Implicit in this image is an idea of the past and of our traditional culture as a universe of pure coherence" ("Praise" 204).

The lack of cultural cohesion in Arrow of God is manifest in the correlative relationship between the two plots, one involving members or relatives of a single family, the other 
involving the larger society. It is palpable, for instance, in the contentious relationship between Ezeulu and Nwaka and their respective villages, Umuachala and Umuneora. That conflict arises out of jealousy and a power struggle of sorts predating European intervention. It begins with the formation of the six-village collective, or more specifically, in the installation of their common deity, Ulu (Arrow 16). The cynical motives are connoted when Nwaka is victorious in the debate with Ezeulu over going to war with Okperi: "Nwaka came from a long line of prosperous men and from a village which called itself first in Umuaro. They said that when the six villages first came together they offered the priesthood of Ulu to the weakest among them lest it became too powerful" (Arrow 17). The disunity over the location of the chief priest is conveyed further in the conflict that arises after Oduche risks killing the sacred python by putting it in a box. That sacrilege serves as a pretext for re-igniting the long-standing feud between Ezeulu and Nwaka, and Nwaka's spiritual guide, Ezidemili:

He [Ezeulu] knew that the priests of Idemili and Ogwugwu and Eru and Udo had never been happy with their secondary role since the villages got together and made Ulu and put him over the other deities. But he would not have thought that one of them would go so far as to set someone to challenge Ulu. It was only the incident of the sacred python that opened Ezeulu's eyes. (Arrow 4)

The cause of the enmity is reiterated when Akuebue visits Ezeulu to discuss the Oduche scandal: "'Everybody knows those two,' said Akuebue. 'We all know that if they knew the way to Ani-nmo they would go to quarrel with our ancestors for giving the priesthood of Ulu to Umuachala and not to their village" (Arrow 147). Here, Ezidemili is one of the two; Nwaka is the other. Akuebue's following declaration to Ezeulu is a poignant reminder of what is a signal problem within the native culture, ante-alienation triggered by fraternal and intra-cultural politics: "'It troubles me,' he said, 'because it looks like the saying of our ancestors that when brothers fight to the death a stranger inherits their father's estate'" (Arrow 250). This proverbial saying sums up nicely my point about colonial intrusions benefiting from ante-alienation. But on that same note, the tragedy of the novel must therefore be seen at least in part as a result of the lack of congeniality in traditional Ibo society.

Irele sees the pathology of alienation effectively expressed in Kane's Ambiguous Adventure. "The hero, Samba Diallo," he says, "is the architype of the divided consciousness, of the African who suffers in his mind the effects of cultural dispossession" ("Praise" 203). Samba's consciousness is divided, yes. But I wonder about the apparent ambiguity of his adventure. I wonder if Katherine Woods is right when in her "Foreword to the American Edition" she contends that Kane "makes no suggestion, in regard to the problem he presents" (vii). Her assertion that "There is no violence" (vi) in the text is also troubling. I wonder if there may not be great irony in the title, since Samba dies violently as a result of the adventure, and this at the hands of a "fool" who had taken a similarly adventurous journey to Europe and, obviously, paid a high price? These ruminations bring to mind the related problems of Tambu, the central protagonist in Tsitsi Dangarembga's Nervous Conditions. At the point of writing down her story, a point marking a milestone in her selfexploration, her "expansion" (Dangarembga 204), Tambu's alienated consciousness is still somewhat divided. However, through the representation of her story, it is a consciousness 
in pursuit of wholeness. It is, after all, not just her story: “The story I have told here, is my own story, the story of four women whom I loved, and our men" (Dangarembga 204). This positive outlook succeeding social and colonial alienation seems to validate Irele's contentious point that Africans could benefit from more alienation (see conclusion of first section above). But, if so, that outlook simultaneously disproves his declaration that all of modern African literature projects the sense that it is in traditional culture that Africans locate their essential correspondence between themselves and the world. Nervous Conditions suggests that Tambu's questioning things (Dangarembga 204), including both the socially alienating gender politics of her community and the psychologically alienating colonial brainwashing, instead of resulting in her happiness and ease in traditional culture, helps to bring her into closer proximity with a more empowered African consciousness. Of course, Irele's "In Praise of Alienation" appeared about one year before Dangarembga's text was first published. But as we have seen in this essay, the tragic outcomes of the interstices of social alienation within traditional culture portrayed by Achebe suggest that, though he may not embrace colonialism's purported benefits wholeheartedly, he is a visionary who would quite concur with Irele's sentiment that "The resources in ideas, techniques, and in certain respects values offered by our traditional cultures are simply not adequate for our contemporary needs and interests" ("Praise" 213). In other words, texts Irele was quite familiar with at the time of his engaging interjection on the topic of alienation, in particular Things Fall Apart, No Longer At Ease, and Arrow of God, challenge the notion that all of modern African literature portray Négritude's deference of that culture.

\section{WORKS CITED}

Achebe, Chinua. Arrow of God. 1967. New York: Anchor Books/Doubleday and Co., Inc., 1969.

- No Longer at Ease. New York: Ivan Obolensky, Inc., 1960.

. Things Fall Apart. 1958. New York: Anchor Books/Random House, 1994.

Bhabha, Homi K. The Location of Culture. New York: Routledge, 1994.

Criswell, Stephen. "Colonialism, Corruption, and Culture: A Fanonian Reading of Mister Johnson and No Longer at Ease." The Literary Griot: International Journal of Black Expressive Cultural Studies, 10.1 (1998): 43-64. Dangarembga, Tsitsi. Nervous Conditions. New York: Seal Press, 1989.

Davis, Gregson. Aimé Césaire. Cambridge: Cambridge UP, 1997.

Fanon, Frantz. Black Skin, White Masks. Trans. Charles Lam Markmann. New York: Grove Weidenfeld, 1967. Gikandi, Simon. Reading Chinua Achebe. Portsmouth, NH: Heinemann, 1991.

Harris, Will. "Okonkwo in Exile: Lessons from the Underworld." CLA Journal 47.1 (2003): 93-104.

Irele, Abiola. "In Praise of Alienation." The Surreptitious Speech: Présence Africaine and the Politics of Otherness 1947-1987. Ed. V. Y. Mudimbe. Chicago: U of Chicago P, 1992. 201-24.

. The African Experience in Literature and Ideology. London: Heinemann, 1981.

Kane, Cheikh Hamidou. Ambiguous Adventure. 1962. New York: Collier Books, 1969.

Said, Edward. Representations of the Intellectual: The 1993 Reith Lectures. London: Vintage, 1994.

wa Thiong'o, Ngũgĩ. Decolonising the Mind: The Politics of Language in African Literature. Westlands, Nairobi: East African Educational Publishers Ltd., 1986.

Woods, Katherine. Foreword. Ambiguous Adventure. By Cheikh Hamidou Kane. New York: Collier Book, 1969. 